\title{
GC-MS analysis and biological activities of Thymus vulgaris and Mentha arvensis essential oil
}

\section{Thymus vulgaris ve Mentha arvensis Uçucu Yağlarının GC-MS Analizi ve Biyolojik Aktivite Tayini}

https://doi.org/10.1515/tjb-2018-0258

Received July 4, 2018; accepted October 17, 2018; previously published online August 1, 2019

\section{Abstract}

Background: Essential oils are chemical products produced by odoriferous glands from a variety of plants. These essential oil have many health benefits i.e. antiseptic, anti-inflammatory and antimicrobial activities. So due to these medicinal properties present study was designed to analyze essential oil of Thymus vulgaris and Mentha arvensis for their chemical composition and biological activities. Materials and methods: Essential oil from these plants were extracted by hydrodistillation method, and analyzed by GC-MS. To test the microbial activity of these oil disk diffusion method and micro wells method were used. For free radical scavenging DPPH assay was used. However total phenolic content was measured by colorimetric method.

Results: The GC-MS analysis of T. vulgaris oil showed the presence of 47 chemical compounds among which thymol, terpinene, p-cymene and carvacrol were major. However essential oil of $M$. arvensis showed the presence of 28 constituents, among which the Menthone, Menthol, Isomenthone, Eucalyptol, neo-Menthol, cis-Piperitone oxide, Linalool, Thymol, Limonene, and $\alpha$-Phellandrene were major. Essential oil from both these plant tested for antimicrobial activity showed that the T. vulgaris oil was effective against seven bacterial strains and the essential oil of $M$. arvensis was effective against six bacterial strain.

\footnotetext{
*Corresponding author: Saboon, Department of Botany, University of Arid Agriculture, Murree Road Rawalpindi, Rawalpindi, Pakistan, e-mail: sabaoon329@gmail.com. https://orcid.org/0000-00018595-5807

Ashfaq Ahmad Khan: Department of Chemistry, Women University of Azad Jammu and Kashmir, Bagh, Pakistan

Muhammad Shoaib Amjad: Department of Botany, Women University of Azad Jammu and Kashmir, Bagh, Pakistan
}

The antioxidant activity of both samples by DPPH assay which showed positive result.

Conclusion: As both species showed the presence of active components, positive microbial activities, and antioxidant activity so, research should be carried on for further biological activities of these oil for betterment of living beings.

Keywords: GC-MS; Hydrodistillation; Antibacterial; Thymus vulgaris; Mentha arvensis.

öz

Amaç: Uçucu yağlar, antiseptik, antiinflamatuvar, antimikrobiyal gibi çeşitli etkileri olan, farklı bitkilerin koku salgı bezleri tarafından üretilen kimyasal ürünlerdir. $\mathrm{Bu}$ çalışma, esansiyel yağların bu tıbbi yararları gözönünde bulundurularak Thymus vulgaris ve Mentha arvensis'in uçucu yağlarının kimyasal bileşimlerinin ve biyolojik aktivitelerinin analizi amacıyla tasarlanmıştır.

Gereç ve yöntem: Bitkilerden elde edilen uçucu yağlar hidrodistilasyon metodu ile ekstrakte edilmiş ve GC-MS ile analiz edilmiştir. Yağların mikrobiyal aktivitesini test etmek için disk difüzyon yöntemi ve mikro kuyucuk metodu kullanılmıştır. Serbest radikal temizleyici etki DPPH yöntemi ile, fenolik içerik ise kolorimetrik metod ile ölçülmüştür.

Bulgular: Her iki uçucu yağın GC-MS analizi sonucunda, T. vulgaris yağının yapısında aralarında timol, terpinen, p-simen ve karvakrolün bulunduğu 47 kimyasal bileşiğin varlığı; $M$. arvensis yağının içeriğinde ise menton, mentol, izomenton, ökaliptol, neo-mentol, cis-piperiton oksit, linalol, timol, limonen ve $\alpha$-felandren bileşenlerini içeren 28 kimyasal bileşenin varlığı tespit edilmiştir. Antimikrobiyal aktiviteleri incelendiğinde, T. vulgaris yağının 7 bakteri suşuna karşı, M. Arvensis uçucu yağının ise 6 bakteri suşuna karşı etkili olduğu belirlenmiştir. Her iki uçucu yağın antioksidan aktivitesi, DPPH testi ile pozitif sonuç göstermiştir. 
Sonuç: Her iki uçucu yağın aktif bileşenlerinin varlı̆̆ı, pozitif mikrobiyal ve antioksidan aktiviteleri, bu yağların biyolojik aktiviteleri ile ilgili daha ileri çalışmalara ihtiyaç olduğunu göstermektedir.

Anahtar kelimeler: GC-MS; hidrodistilasyon; antibakteriyal; Thymus vulgaris; Mentha arvensis.

\section{Introduction}

Since ancient times, people used herbs and parts of plants as food and medicine and with the passage of time instead of plant parts, plant products are also utilized for phytotherapy like essential oils from aromatic plants, are used to treat different aliments due to wide array of biological activities i.e. antiseptic, anticancer, spasmolytic, hepatoprotective, antimicrobial, antioxidant, and pesticidal [1]. These essential oil are mostly utilized in aromatherapy to treat different disorders. The essential oils are chemical products with low boiling point, greatly soluble in organic solvents, produced by odoriferous glands in a great variety of plants. These oils accumulate in all parts (leaves, barks, woods, flowers, fruit, rhizomes and seeds) of the plant. These oil contain different chemical compounds due to which they have many important pharmacological properties. Some of the chemical components (d-limonene, $d$-carvone or geranyl acetate) of these essential oils are used at industrial level as a scents, cosmetics, detergents, taste makers, cleansers and as solvents.

Due to different biological activities, a strong interest is developed from last few years in essential oils collected from different odoriferous plants [2]. Until now about 3000 essential oils are observed from different plants species, out of these 300 have commercial importance as medicine, nutriment and cosmetics. One of the famous aromatic plant families is Lamiaceae, this family is important due to production of their essential oil from odoriferous plants. This family consists of about 252 genera and more than 6700 species [3]. Essential oils from the members of this family known to possess antiseptic, anti-inflammatory and antimicrobial activities [4]. So due to vast medicinal properties present study was designed to analyze essential oil from two members (Thymus vulgaris and Mentha arvensis) of this family.

\section{Materials and methods}

\section{Collection of sample}

Whole plant of T. vulgaris L. (Figure 1) at flowering stage were gathered from Ganga Choti, a mountain lying in

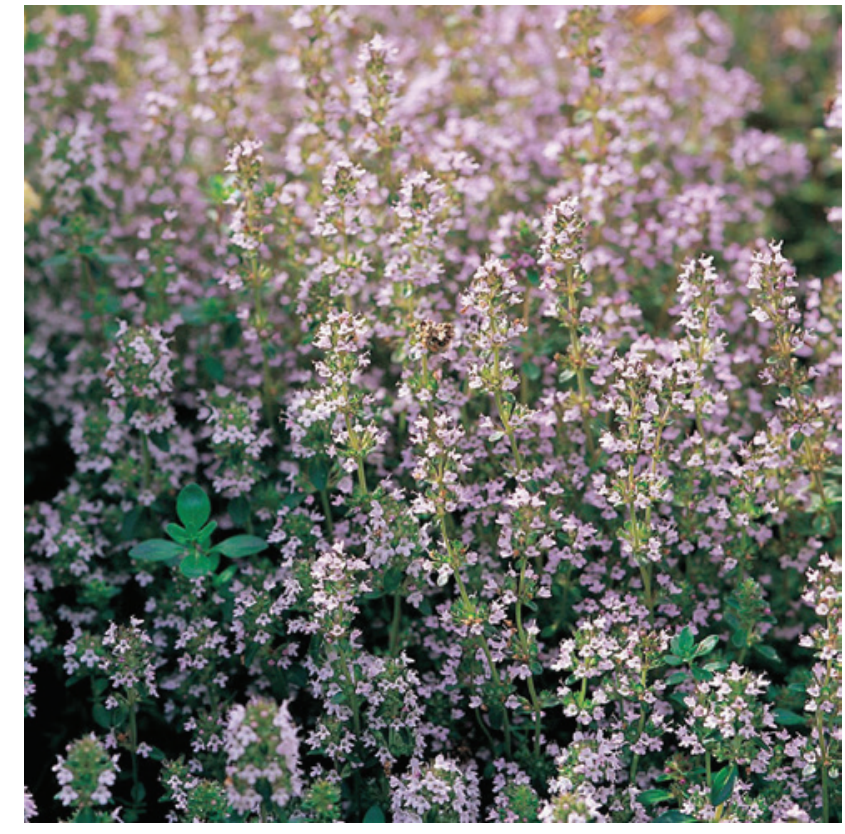

Figure 1: Thymus vulgaris.

Source: https://farmyardnurseries.co.uk.

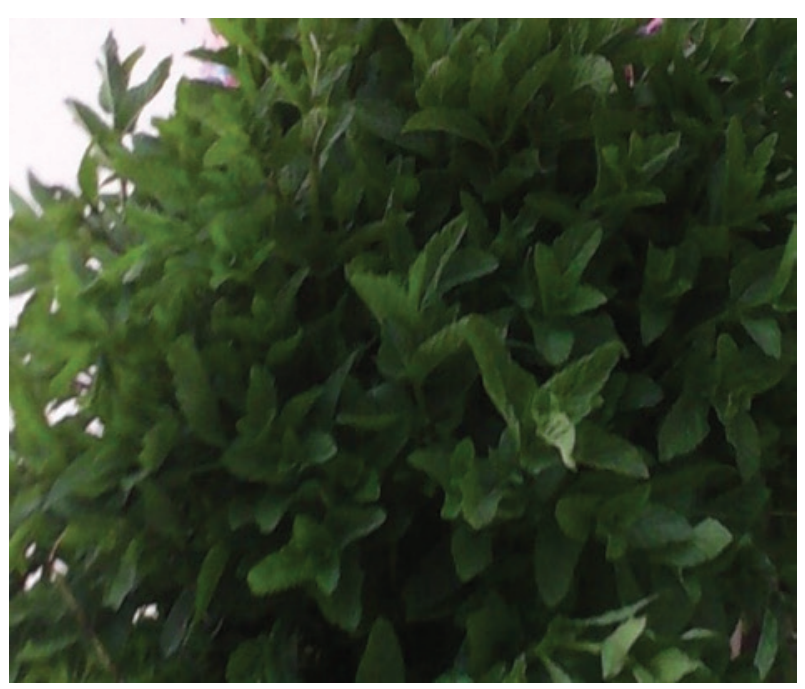

Figure 2: Mentha arvensis.

Bagh, Azad Kashmir, Pakistan and the fresh aerial parts of M. arvensis L. (Figure 2) were collected from Muzaffarabad, Azad Kashmir, Pakistan. Plant species were identified with the help of literature and authenticated by taxonomist. Samples of plants are shad dried, converted into fine powder and stored at room temperature for later use.

\section{Hydrodistillation extraction}

Extraction of essential oil was done by hydrodistillation method with Clevenger apparatus shown in Figure 3, 


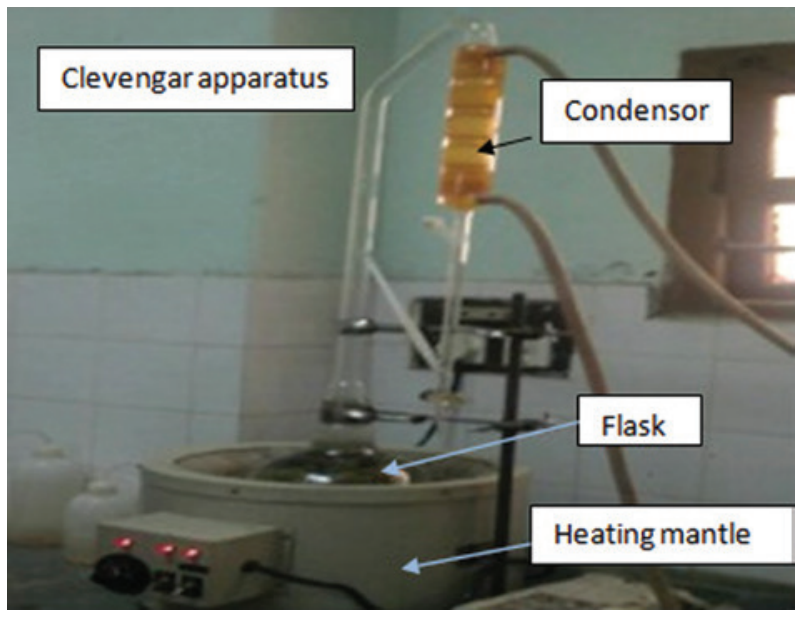

Figure 3: Hydrodistillation apparatus.

following the protocol of European Pharmacopoeia [5, 6]. Sixty gram of dried thyme powder with 2.5 -L water was poured into the apparatus and extraction was carried out for $2 \mathrm{~h}$ until no more oil was left. Thyme oil was decanted after every fraction and collected in Eppendorf tubes. The oil was dried with anhydrous sodium sulfate. After that the oil was stored at refrigerator at $4^{\circ} \mathrm{C}$.

For extraction of oil from $M$. arvensis the protocol of Souza et al. [7] was followed, $1 \mathrm{~kg}$ of fresh leaves were grind and put into the distillation apparatus. The remaining container was filled with $2.5 \mathrm{~L}$ distilled water the processes was carried out for $2 \mathrm{~h}$ to obtain maximum oil. Same process was repeated until no more oil was left. Mentha oil was decanted after every fraction and collected in Eppendorf tubes. The oil was dried on anhydrous sodium sulfate and stored at $4^{\circ} \mathrm{C}$ before GC-MS Analysis.

\section{Gas chromatography/mass spectrometry (GC/MS) analysis}

Both samples of essential oil were analyzed by GC-MS (Hewlett-Packard model 6890 and Agilent 7890A, USA) by following the protocol of Negahban and Saeedfar [8]. Essential oil were observed by Hewlett-Packard model 6890 (Figure 4) working at ionization energy of $75 \mathrm{eV}$ with a DB-5 capillary tube of $0.25 \mathrm{~mm}$ diameter, $0.25 \mu \mathrm{m}$ film thickness and $30 \mathrm{~m}$ length. The temperature was set to increase with regular interval of time from 60 to $23^{\circ} \mathrm{C}$ at $5^{\circ} \mathrm{C} / \mathrm{min}$. Helium was used as a carrier gas at $1.5 \mathrm{~mL} / \mathrm{min}$. MS source temperature was retained at $20^{\circ} \mathrm{C}$, sample injection volume was 3 $\mu \mathrm{L}$, split ratio was $1: 60$, interface temperature was $230^{\circ} \mathrm{C}$ and mass scan was 30-655 atomic mass unit.

The analysis was carried on Agilent 7890A attached with FID (Flame Ionization Detector), narrow capillary column $(0.25 \mathrm{~mm}$ diameter, $0.25 \mu \mathrm{m}$ film thickness and

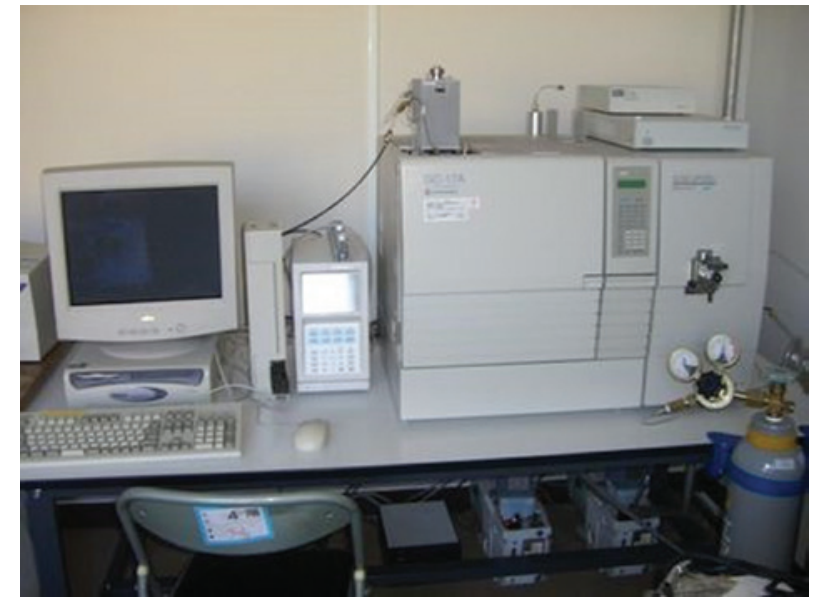

Figure 4: GC-MS apparatus.

$30 \mathrm{~m}$ length). The temperature was set to increase with regular interval of time from 60 to $230^{\circ} \mathrm{C}$ at $5^{\circ} \mathrm{C} / \mathrm{min}$. Nitrogen gas was used as Carrier gas at $2 \mathrm{~mL} / \mathrm{min}$. Quantitative data were obtained from FID area percentages.

\section{Identification of components}

For identification of compounds after the oil at same conditions $n$-alkanes series was injected to calculate the retention index (RI) of all volatile constituents. The constituents were identified by comparison of their RI with the saved library data such as New York mass spectral library, Wiley Library and by comparison of the fragmentation patterns of the mass spectra with those reported in the literature $[9,10]$.

\section{Antibacterial activity}

Essential oil of T. vulgaris was tested on six different strains of bacteria (Enterococcus faecalis, Escherichia coli, Klebsiella pneumoniae, Staphylococcus aureus, Pseudomonas aeruginosa and Salmonella typhimurium) by using disk diffusion method. For the assay microorganism suspension $\left(10^{6} \mathrm{cell} / \mathrm{mL}\right)$ was poured on the solid media plate (MullerHinton agar). Filter paper (Whatman No. 1, pore size $11 \mu \mathrm{m}$ ) were impregnated with different concentrations $(5,10,15$ and $20 \mu \mathrm{L}$ ) of essential oil and put on the prepared agar. The plates were then inoculated for $26 \mathrm{~h}$ at $38^{\circ} \mathrm{C}$. Ciprofloxacin $(25 \mu \mathrm{g} /$ disk $)$ and cephalexin $(15 \mu \mathrm{g} /$ disk $)$ were used as positive controls. The diameter of the zone of inhibition after incubation was calculated in millimeters and quantitative data was generated from these results.

The antibacterial activities of $M$. arvensis was tested with the help of broth dilution assay. The assay was performed in $0.2 \%$ sterile peptone water. The same bacterial 
strains were used for T. vulgaris antioxidant activity were suspended in that water with the turbidity visually corresponding to 0.6 Mc Farland. Different dilution (0.09-50.1\%) of the oil were made. Fifty microliter of bacterial suspension was inoculated into micro wells with the same amount of essential oil dilution and incubated at $38^{\circ} \mathrm{C}$ for $26 \mathrm{~h}$. After incubation minimum inhibitory concentration (MIC) was determined. Experiment was performed in triplicates.

\section{Antifungal activities}

Antifungal activities was carried out on Candida albicans by using Sabouraud agar and Malt Extract-Agar. For toxicity measurement poisoned food technique was used. For the assay inoculum was taken on $5 \mathrm{~mm}$ diameter disc and put at the mid of each petri plate containing PDA media. $0.5 \mathrm{~mL}$ of different concentration $(0,0.7,1.30,2.7,5.5,10.6$, $100 \mu \mathrm{L} \mathrm{mL}{ }^{-1}$ ) of both samples were then incubated at $30^{\circ} \mathrm{C}$ for 6-7 days with these culture. Fluconazole ( $15 \mu \mathrm{g} /$ disk) was used as positive control. For quantitative data, percentage inhibition of mycelia was measured one by one.

\section{Total phenolic content}

To check percentage of phenolic contents, colorimetric method was used by following the protocol of [11]. Gallic acid solution was used as a standard.

\section{Anti-oxidant activity}

The essential oil of T. vulgaris was checked for anti-oxidant property on 2,2-diphenyl-1-picrylhydrazyl (DPPH) by following the protocol of $[12,13]$. For that, $5 \mathrm{~mL}$ of DPPH solution were taken with four different concentrations of extract. After incubation for $20 \mathrm{~min}$ the absorbance of sample was measured at $517 \mathrm{~nm}$ with spectrophotometer. Methanol was taken as blank and quercetin as reference compound.

Percentage inhibition was measured by following formula

Percent inhibition $(\%)=\left[\left(\mathrm{A}_{\text {blank }}-\mathrm{A}_{\text {sample }}\right) / \mathrm{A}_{\text {blank }}\right] \times 100$

\section{Results and discussion}

\section{Chemical composition of essential oil}

Oil obtained from T. vulgaris is known as yellow oil. That yellow oil was subject for its chemical constituents result
Table 1: Essential oil compositions in T. vulgaris.

\begin{tabular}{|c|c|c|c|}
\hline No. & Compounds & $\mathbf{R}^{\mathbf{a}}$ & $\% \mathrm{RA}^{\mathrm{b}}$ (means $\left.\pm S D\right)$ \\
\hline 1. & $\alpha$-Thujene & 929 & $0.86 \pm 0.19$ \\
\hline 2. & $\alpha$-Pinene & 935 & $0.59 \pm 0.14$ \\
\hline 3. & Camphene & 950 & $0.53 \pm 0.13$ \\
\hline 4. & Sabinene & 975 & $0.04 \pm 0.03$ \\
\hline 5. & 1-Octen-3-ol & 981 & $0.24 \pm 0.09$ \\
\hline 6. & 3-Octanone & 987 & $0.07 \pm 0.03$ \\
\hline 7. & Myrcene & 994 & $1.23 \pm 0.03$ \\
\hline 8. & 3-Octanol & 998 & $0.19 \pm 0.03$ \\
\hline 9. & $\alpha$-Phellandrene & 1008 & $0.26 \pm 0.13$ \\
\hline 10. & $\delta$-3-Carene & 1013 & $0.09 \pm 0.03$ \\
\hline 11. & $\alpha$-Terpinene & 1019 & $1.25 \pm 0.12$ \\
\hline 12. & P-Cymene & 1026 & $8.55 \pm 0.84$ \\
\hline 13. & Limonene & 1034 & $0.09 \pm 0.03$ \\
\hline 14. & 1,8-Cineole & 1035 & $0.69 \pm 0.16$ \\
\hline 15. & (Z)- $\beta$-Ocimene & 1038 & - \\
\hline 16. & Benzene acetaldehyde & 1045 & - \\
\hline 17. & (E)- $\beta$-Ocimene & 1049 & $0.18 \pm 0.05$ \\
\hline 18. & $\gamma$-Terpinene & 1065 & $9.48 \pm 1.84$ \\
\hline 19. & Cis-Sabinene hydrate & 1070 & $0.85 \pm 0.25$ \\
\hline 20. & Terpinolene & 1090 & $3.14 \pm 0.59$ \\
\hline 21. & Linalool & 1105 & $0.10 \pm 0.05$ \\
\hline 22. & Camphor & 1145 & $0.13 \pm 0.05$ \\
\hline 23. & Borneol & 1167 & $1.26 \pm 0.33$ \\
\hline 24. & Terpinene-4-ol & 1179 & $0.23 \pm 0.09$ \\
\hline 25. & $\gamma$-Terpineol & 1210 & $0.26 \pm 0.05$ \\
\hline 26. & Thymol methyl ether & 1237 & $0.65 \pm 0.15$ \\
\hline 27. & Carvacrol methyl ether & 1245 & $0.40 \pm 0.13$ \\
\hline 28. & Thymol & 1301 & $60.55 \pm 2.27$ \\
\hline 29. & Carvacrol & 1315 & $3.36 \pm 0.76$ \\
\hline 30. & Eugenol & 1361 & $0.05 \pm 0.03$ \\
\hline 31. & Isobornyl propionate & 1379 & $0.37 \pm 0.12$ \\
\hline 32. & $\beta$-Bourbonene & 1387 & $0.09 \pm 0.02$ \\
\hline 33. & (E)-Caryophyllene & 1423 & $1.75 \pm 0.24$ \\
\hline 34. & Aromadendrene & 1440 & $0.09 \pm 0.03$ \\
\hline 35. & $\alpha$-Humulene & 1455 & $0.15 \pm 0.09$ \\
\hline 36. & Geranyl propanoate & 1476 & $0.15 \pm 0.08$ \\
\hline 37. & $\gamma$-Murolene & 1478 & $0.25 \pm 0.13$ \\
\hline 38. & Germacrene-D & 1482 & $0.14 \pm 0.05$ \\
\hline 39. & Valencene & 1496 & - \\
\hline 40. & 'Y-Cadinene & 1515 & $0.20 \pm 0.05$ \\
\hline 41. & $\delta$-Cadinene & 1525 & $0.24 \pm 0.12$ \\
\hline 42. & $\alpha$-Cadinene & 1538 & - \\
\hline 43. & Spathulenol & 1579 & $0.13 \pm 0.05$ \\
\hline 44. & Caryophylene oxide & 1584 & $0.35 \pm 0.16$ \\
\hline 45. & 10-epi- $\gamma$-Eudesmol & 1620 & $0.13 \pm 0.06$ \\
\hline 46. & EPI- $\alpha$-Cadinol & 1642 & - \\
\hline 47. & $\alpha$-Cadinol & 1655 & $0.19 \pm 0.05$ \\
\hline \multirow[t]{2}{*}{48.} & Oil yield $(\% w / w)$ & & $1.55 \pm 1.27$ \\
\hline & Total & & 99.5 \\
\hline
\end{tabular}

${ }^{\mathrm{a}} \mathrm{RI}$, retention index.

${ }^{b} R A$, relative area percentage values are means of three experiments \pm SD. 
of the study showed the presence of 47 recognized chemical constituents shown in Table 1. The compounds with higher percentage were terpinolene $(3.15 \%)$, p-cymene (8.53\%), $\gamma$-terpinene (9.48\%), carvacrol (3.35\%) and thymol $(60.55 \%)$. These result were agree with that of Negahban and Saeedfar [8], these researcher also showed the higher percentage of thymol (49\%), $\beta$-cymene $(19.99 \%)$, carvacrol (7.63\%) and trans-caryophyllene (6.79\%) in T. vulgaris. Miladi et al. also showed the higher percentage of thymol (52.19\%) followed by content of carvacrol (6.72\%) [1]. In different studies the percentage of these chemical components are slightly vary from each other one of the research relate these variation to the different climatic conditions of the world which vary in different geographical region of the world. Quantity may also vary due to health and variety of the plant, age of the plant at the time of collection, method of drying and to the method of extraction of the oil from samples [14]. The effect of different geographical zone on percentage composition was also confirmed by the research of Satyal et al. [6] who worked on thyme collected from different regions the result of their study showed that the T. vulgaris collected from France showed higher percentage of linalool (76.2\%) and linalyl acetate (14.3\%) where the thyme obtained from Serbia showed the higher presence of geraniol $(59.8 \%)$ geranyl acetate $(16.7 \%)$. In literature study it is also observed that the amount of carvacrol is also higher in other species such as Thymus pallescens de Noé an endemic plant of Algeria reported by Sadjia et al. [15]. In our study the percentage of other components was observed less than $2 \%$. A high correlation was observed between $\gamma$-terpinene and p-cymene with thymol and carvacrol contents in essential oil of T. vulgaris shown in Table 2.

The GC-MS analysis of $M$. arvensis essential oil showed the presence of total 28 chemical components in which most are recognized and cited in previous researcher work these compound are given in Table 3. Components with high percentage were: $\alpha$-Phellandrene (3.22\%), Dl-Limonene (1.48\%), linalool (2.22\%), Linalool (2.22\%), cis-Piperitone oxide (3.63\%), Menthone (29.42\%), neo-Menthol (4.75\%), Eucalyptol (6.95\%), Isomenthone (10.85\%), Menthol (21.35\%), and Thymol (1.64\%) and some other components with small amount were also identified. Our results agree with that of Souza et al. [7] they showed the presence of menthol (67.27\%) and menthone (13.34\%) in highest amount in young leaves of $M$. arvensis. In another study, researcher showed the presence of 25 different components in the essential oil of $M$. arvensis in which the higher concentration was observed of menthol and menthone [7]. Some researcher showed that the percentage of chemical component in essential oil can vary in different cultivar of mint and at different growing stage [16]. However literature study showed that essential oil concentration increases at mature stage of $M$. arvensis [7]. Overall the result of our findings are compatible with those reported in literature.

\section{Antimicrobial activity}

The quantitative result of antimicrobial activity of $T$. vulgaris essential oil against different bacterial strain are given in Table 4. Results of our study showed that the antimicrobial potential of $T$. vulgaris essential was concentration dependent by increasing concentration antimicrobial activity also increased. Secondly the effectiveness of essential oil was different against different bacterial strains i.e. high inhibition zone was observed in K. pneumonia, E. coli and S. typhimurium. To compare more thoroughly the effect of T. vulgaris on each microorganism (Figure 5 and Table 4) shows the results of multiple comparisons, at each oil amount, was assumed. Essential oil was checked in different pair to compare with each other. All the pairwise differences showed that they are highly significant $(\mathrm{p}=0.00)$ with each other except $S$. typhimurium and E. coli. The growth of K. pneumoniae, E. faecalis, S. aureus, P. aeruginosa and E. coli was previously recorded along with the efficacy against S. typhimurium, respectively [17]. However, some studies report the inefficiency of thyme essential oil against $E$. coli, S. aureus and K. pneumonia [18]. Ciprofloxacin and cephalexin was used as positive control. Vast variety of essential oils activity depends on chemical components. Previous studies by the researcher showed a strong relationship of the antimicrobial activities with the presence of phenolic compounds i.e. thymol and $\gamma$-terpinene present in essential oil, except p-cymene, which does not show antibacterial efficacy when used alone, but in

Table 2: Thymol, p-cymene, $\gamma$-terpinene and carvacrol contents of the essential oil in T. vulgaris.

\begin{tabular}{lrrrrr}
\hline Plant & Thymol (\%) & p-cymene (\%) & $\boldsymbol{\gamma}$-terpinene (\%) & Carvacrol (\%) & Total (\%) \\
\hline T. vulgaris & $60.55 \pm 2.28$ & $8.53 \pm 0.85$ & $9.48 \pm 1.85$ & $3.35 \pm 0.75$ & 82.0 \\
\hline
\end{tabular}

Values are the average of three experiments \pm SD. $p<0.05$. 
Table 3: Essential oil composition in M. arvensis.

\begin{tabular}{|c|c|c|c|c|c|}
\hline S. no. & $\mathbf{R T}^{\mathbf{a}}$ & Constituents & $\mathbf{R} \mathbf{I}^{\mathbf{b}}$ & $\mathbf{R} \mathbf{l}^{\mathbf{c}}$ & $\mathbf{R A}^{\mathrm{d}}$ \\
\hline 1. & 3.872 & dl-Limonene & - & 1155 & 1.48 \\
\hline 2. & 4.049 & Eucalyptol & - & 1207 & 6.92 \\
\hline 3. & 4.459 & $\alpha$-Pinene & - & 1040 & 0.69 \\
\hline 4. & 4.663 & $\beta$-Pinene & - & 1040 & 1.14 \\
\hline 5. & 4.789 & $\delta$-3-Carene & 1202 & 1148 & 0.21 \\
\hline 6. & 5.175 & $\alpha$-Phellandrene & 1218 & 1217 & 3.22 \\
\hline 7. & 6.784 & Octyl cyclobutane carboxylate & 1284 & - & 0.33 \\
\hline 8. & 8.368 & 3-Octanol & 1341 & 1383 & 1.83 \\
\hline 9. & 10.21 & L-Menthone & 1403 & 1458 & 29.42 \\
\hline 10. & 10.368 & cis-Sabinene hydrate & 1406 & 1522 & 0.70 \\
\hline 11. & 10.963 & Isomenthone & 1427 & 1454 & 3.84 \\
\hline 12. & 12.917 & Linalool & 1489 & 1540 & 2.22 \\
\hline 13. & 13.135 & neo-Menthol acetate & 1496 & - & 0.30 \\
\hline 14. & 13.875 & trans-Caryophyllene & 1519 & - & 0.52 \\
\hline 15. & 14.211 & neo-Menthol & 1530 & 1598 & 4.73 \\
\hline 16. & 14.343 & 4-Terpineol & 1535 & 1553 & 0.30 \\
\hline 17. & 15.545 & Menthol & 1575 & 1614 & 21.35 \\
\hline 18. & 16.294 & trans-Anethole & 1598 & 1810 & 1.63 \\
\hline 19. & 16.446 & $\delta$-Terpineol & 1603 & 1656 & 0.23 \\
\hline 20. & 17.138 & 2-Acetylfuran & 1626 & - & 1.37 \\
\hline 21. & 17.228 & $\alpha$-Terpineol & 1627 & 1688 & 0.43 \\
\hline 22. & 17.384 & cis-Piperitone oxide & 1634 & 1701 & 3.63 \\
\hline 23. & 17.974 & Isomenthone & 1655 & 1453 & 6.99 \\
\hline 24. & 18.209 & 5-Isopropyl-6,7-epoxy-8-hydroxy-8-methylnon-2-One & 1664 & - & 0.37 \\
\hline 25. & 22.752 & 2,6,6-Trimethyl-cyclohex-1-enecarboxylic acid & 1670 & - & 0.42 \\
\hline 26. & 24.359 & 3-Methyl-3-(4-methyl-3-pentenyl) oxiranemethanol & 1876 & - & 0.17 \\
\hline 27. & 24.587 & Caryophyllene oxide & 1885 & 1929 & 0.54 \\
\hline 28. & 27.784 & 2,5-Dimethyl-3-hexyne-2,5-diol & 2000 & - & 0.55 \\
\hline
\end{tabular}

${ }^{\text {aRT, retention time. }}$

${ }^{\mathrm{b}} \mathrm{RI}$, retention indices on BP-20 polar column.

'RI, actual retention indices of columns (Supelcowax-10, HP-20M, CW-20M and BP-20).

${ }^{\mathrm{d}} \mathrm{RA}$, components percentage.

Table 4: Antimicrobial activity of T. vulgaris.

\begin{tabular}{lrrrr}
\hline Test microorganism & $\begin{array}{r}\text { Amount of } \\
\text { essential oil }(\mathbf{5} \boldsymbol{\mu L})\end{array}$ & $\begin{array}{r}\text { Amount of } \\
\text { essential oil }(\mathbf{1 0} \boldsymbol{\mu L})\end{array}$ & $\begin{array}{r}\text { Amount of } \\
\text { essential oil (15 } \boldsymbol{\mu L})\end{array}$ & $\begin{array}{r}\text { Amount of } \\
\text { essential oil (20 } \boldsymbol{\mu L})\end{array}$ \\
\hline Staphylococcus aureus & $24.0 \pm 0.34$ & $29.5 \pm 0.7$ & $30 \pm 0.36$ & $31.6 \pm 0.48$ \\
Salmonella typhimurium & $14.5 \pm 0.35$ & $20 \pm 0.40$ & $31.5 \pm 0.35$ & $35 \pm 0.25$ \\
Pseudomonas aeruginosa & $12 \pm 0.27$ & $13.35 \pm 0.34$ & $14 \pm 0.23$ & $15 \pm 0.20$ \\
E. coli & $14.7 \pm 0.37$ & $20 \pm 0.42$ & $31 \pm 0.32$ & $35 \pm 0.20$ \\
Klebsiella pneumoniae & $31 \pm 0.13$ & $31.05 \pm 0.32$ & $32 \pm 0.25$ & $33.98 \pm 0.15$ \\
Enterococcus faecalis & $9 \pm 0.16$ & $16 \pm 0.16$ & $16 \pm 0.19$ & $25 \pm 0.16$ \\
Candida albicans & $16 \pm 0.39$ & $19.5 \pm 0.56$ & $25.75 \pm 0.25$ & $30.5 \pm 0.18$ \\
\hline
\end{tabular}

Effects of thyme oil against bacteria representing by the mean sizes of the inhibitory zones.

synergistic with thymol and $\gamma$-terpinene it showed effective antibacterial activity.

The antimicrobial activities of $M$. arvensis revealed that its essential oil is effective against all bacterial strains as shown in (Table 5 and Figure 6). Our study showed that the menthol essential oil was more effective against microorganism as compared to thyme oil. Even a low concentration of oil was effective to inhibit $S$. aureus and $E$. coli. Minimal bactericidal concentration of $M$. arvensis essential oil, to inhibit growth of different bacteria was, 


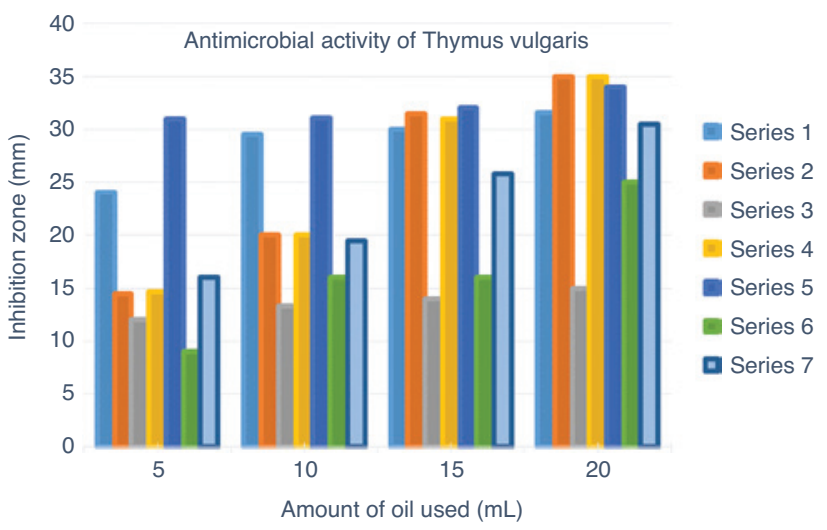

Figure 5: Essential oil antimicrobial activity of Thymus vulgaris. Series 1: Staphylococcus aureus; Series 2: Salmonella typhimurium; Series 3: Pseudomonas aeruginosa; Series 4: E. coli; Series 5: Klebsiella pneumonia; Series 6: Enterococcus faecalis; Series 7: Candida albicans.

Table 5: Antibacterial activity of $M$. arvensis.

\begin{tabular}{llrr}
\hline Series \# & Test organism & $\begin{array}{r}\text { Amount of } \\
\text { essential oil }(\boldsymbol{\mu L})\end{array}$ & $\begin{array}{r}\text { \% Inhibition } \\
\text { (means } \pm \text { SD) }\end{array}$ \\
\hline Series 1 & E. Coli & 0.2 & $(5.8 \pm 5.7)$ \\
Series 2 & E. facium & 0.2 & $(50.7 \pm 17.8)$ \\
Series 3 & St. aureus & 0.2 & $(1.20 \pm 1.8)$ \\
Series 4 & P. aeriginosa & 0.2 & $(38.8 \pm 24.7)$ \\
Series 5 & P. mirabilis & 0.2 & $(30.0 \pm 18.2)$ \\
Series 6 & C. albicans & 0.2 & $(69.67 \pm 32.5)$ \\
\hline
\end{tabular}

These values are average of three experiments \pm SD. $p<0.05$.

E. coli (5.8 \pm 5.7$)$ and S. aureus (1.20 \pm 1.8$)$. Like thymol, the researcher relate the antibacterial property of menthol to the presence of terpenoids present in mint family. In our study, the essential oil of $M$. arvensis was observed rich in terpenoids due to which the essential oil showed strong activity against different bacterial strains. The result of our study was agreed to that of Mickienė et al. [19] worked

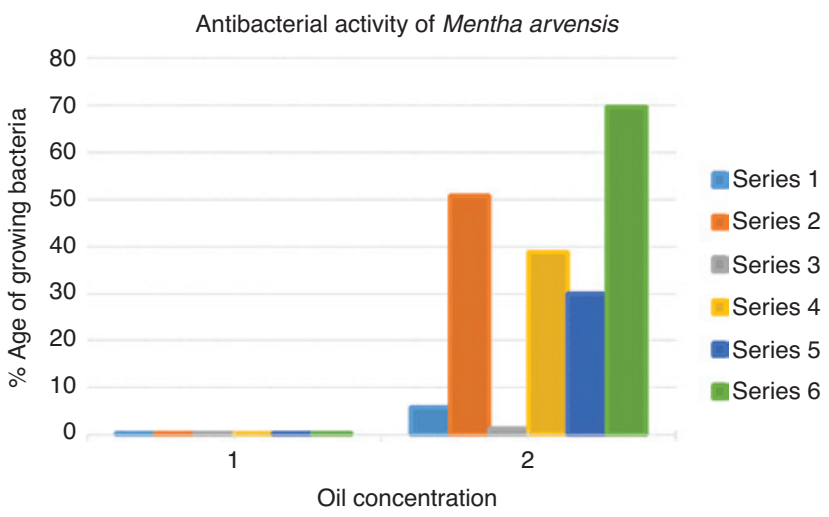

Figure 6: Antibacterial activity of $M$. arvensis.

on different strains of bacteria i.e. S. aureus, Enterococcus faecium, P. aeruginosa, E. coli, Proteus mirabilis. Horváth and Koščová [20] worked on the essential oil of $M$. arvensis against $S$. aureus also showed that the plant essential oil is effective against microorganisms.

The antifungal activity of essential oil of samples showed different values i.e. for $C$. albicans mycelia inhibition $(0 \%, 10 \%, 63.50 \%, 72.30 \%, 88.60 \%, 90.25 \%$ and $94.6 \%, 97.1 \%, 97.75 \%, 99 \%$ and $100 \%$ ) at concentration of $0,0.7,1.30,2.7,5.5,10.6,23,32,42,55,100 \mu \mathrm{LL}^{-1}$ (Table 6). From our present results it was observed that the antifungal activity was concentration dependent, as with increase concentration the antifungal activity also increases. Our present study are agreed with that of Mickiene et al. [19] worked on the antimicrobial activity of essential oil obtained from $M$. arvensis, showed inhibition of $C$. albicans at higher concentration. These essential oil are not only effective against $C$. albicans but also against other fungal strain. The literature study revealed the effectiveness of T. vulgaris against Rhizopus oryzae [21]. Quantitative details are shown in Table 6; Figure 7.

Therefore, our study confirm that essential oil of both plants exhibit stronger antimicrobial activity than that of

Table 6: Percent inhibition of mycelia growth on essential oil of $M$. arvensis.

\begin{tabular}{|c|c|c|c|c|c|c|c|c|}
\hline \multirow[t]{2}{*}{ No. } & \multirow{2}{*}{$\begin{array}{l}\text { Concentration } \\
\text { of oil }\left(\mu \mathrm{LL}^{-1}\right)\end{array}$} & \multirow{2}{*}{$\begin{array}{l}\text { Inoculum } \\
\text { size (mm) }\end{array}$} & \multicolumn{3}{|c|}{ Colony size (mm) } & \multirow{2}{*}{$\begin{array}{r}\text { Mean colony } \\
\text { size }(\mathrm{mm})\end{array}$} & \multirow{2}{*}{$\begin{array}{r}\text { Mycelial } \\
\text { growth }(\mathrm{mm})\end{array}$} & \multirow{2}{*}{$\begin{array}{l}\text { \% Inhibition of } \\
\text { mycelial growth }\end{array}$} \\
\hline & & & I & II & III & & & \\
\hline 1. & 0 & 4 & 42 & 42 & 42 & 42 & 38 & 0 \\
\hline 2. & 0.7 & 4 & 19 & 18 & 19 & 18.67 & 14.67 & 10 \\
\hline 3. & 1.30 & 4 & 12 & 11 & 12 & 11.67 & 7.67 & 63.5 \\
\hline 4. & 2.7 & 4 & 8 & 7 & 8 & 7.67 & 3.67 & 72.30 \\
\hline 5. & 5.5 & 4 & 4 & 4 & 4 & 4.00 & 0.00 & 88.60 \\
\hline 6. & 10.6 & 4 & 4 & 4 & 4 & 4.00 & 0.00 & 90.25 \\
\hline 7. & 100.0 & 4 & - & - & - & - & - & 100.0 \\
\hline
\end{tabular}

$M I C=5.5 \mu \mathrm{LL}^{-1}$. 


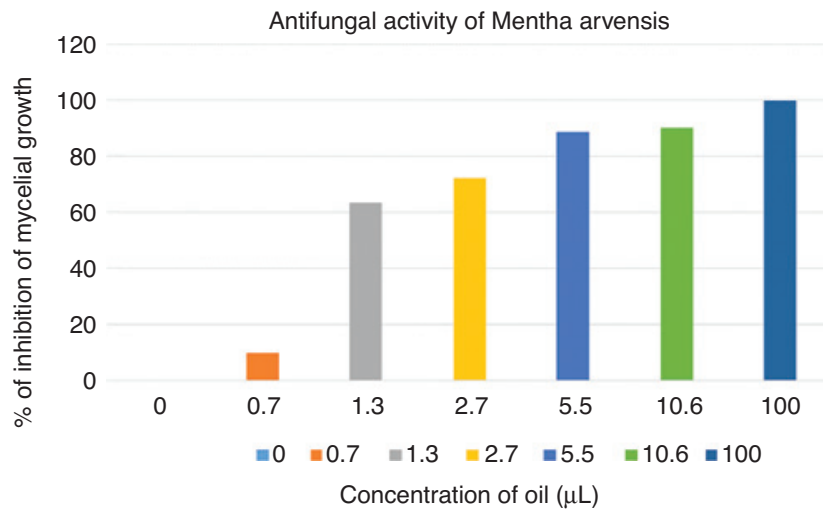

Figure 7: Antifungal activity of $M$. arvensis.

Table 7: Antioxidant activity and total phenolic content in $T$. vulgaris.

\begin{tabular}{|c|c|c|}
\hline Plant & $\begin{array}{r}\text { Total phenolic } \\
\text { content }^{\mathrm{a}} \\
\text { (mg GAE/g DW) }\end{array}$ & $\begin{array}{r}\text { Antioxidant } \\
\text { activity } \\
\left(\mathrm{IC}_{50}\right)^{\mathrm{b}}(\mu \mathrm{g} / \mathrm{mL})\end{array}$ \\
\hline Thymus vulgaris & $21.6 \pm 0.12$ & $7.8 \pm 0.08$ \\
\hline
\end{tabular}

their major constituents or their mixtures, respectively, which suggests synergistic effects of the minor components, but also the importance of all components in relation to the biological activity of essential oils.

\section{Total phenolic content and antioxidant activity}

Many health issues like cancer and heart diseases are caused by free radicals. Literature study showed that plant extracts containing phenolic compounds, exhibit high antioxidants properties. These chemical constituents protect the body against harmful chemicals produce during metabolism of fats [13, 22]. In our present study both samples of essential oil were checked for their total phenolic content. Phenolic contents of both samples of T. vulgaris and $M$. arvensis was expressed as gallic acid equivalent by following the standard curve equation: $\mathrm{y}=0.027 \mathrm{x}+0.1784, \mathrm{R} 2=0.9966$. In our finding we observed high phenol content in T. vulgaris (21.6 mg GAE/g dry weight) as compared to $M$. arvensis values are shown in Table 7.

The free radical scavenging activity of these essential oil were assessed with the help of DPPH assay. During the study it was observed that the high content of phenol in $T$. vulgaris $(7.8 \mu \mathrm{g} / \mathrm{mL})$ lead to the high antioxidant activity as shown in Table 7. So a correlation was observed between radical scavenging capacity and total phenolic content of essential oil. So we can say that the Phenolic compounds play a very important role in scavenging of free radicals. In our finding it was also observed that with increasing concentration the free radical scavenging also increases. Our findings agree with that of Alizadeh [23] work on the antioxidant activity of $T$. vulgaris by using DPPH assay. However, in literature study it was observed that the antioxidant activity of plants are not only caused by phenolic constituents but also due to the presence of other secondary metabolites like vitamins, flavonoids and carotenoids [24]. From these results we can suggest that T. vulgaris is a strong antioxidant can be used as natural antioxidants.

\section{Conclusion}

Present study showed that plant essential oil are good in their biological activities. Both essential oil was rich in chemical composition and showed the presence of many important chemical constituents. Essential oil of M. arvensis and T. vulgaris showed positive results for all biological activities. However, high antioxidant activity was observed in T. vulgaris which also show a strong correlation to the presence of high phenolic content. As both species have active components due to which they showed positive antimicrobial activities. So, research should be carried on for further biological activities of these oil for betterment of living beings. It is also a suggestion that instead of common hydrodistillation technique an improved technique such as Solvent-free microwave extraction (SFME) should be utilized for extraction of essential oil.

Acknowledgment: The author is grateful to the Higher Education Commission Pakistan", "Department of Chemistry", Women university of Azad Jammu and Kashmir, Bagh, University of Azad Jammu and Kashmir, Muzaffarabad and COMSATS Institute of Information Technology, Lahore for providing necessary facilities and support.

\section{References}

1. Miladi H, Slama RB, Mili D, Zouari S, Bakhrouf A. Essential oil of Thymus vulgaris L. and Rosmarinus officinalis L.: gas chromatography-mass spectrometry analysis, cytotoxicity and antioxidant properties and antibacterial activities against foodborne pathogens. Nat Sci 2013;5:729-39. 
2. Bakkali F, Averbeck S, Averbeck D, Idaomar M. Biological effects of essential oils - a review. Food Chem Toxicol 2008;46:446-75.

3. Hedge C. A global survey of the biogeography of the Labiatae. In: Harley RM, Reynolds T, editors. Advances in Labiatae Science. Kew, London: Royal Botanic Gardens, 1992:7-17.

4. Bozin B, Mimica-Dukic N, Anackov G. Characterization of the volatile composition of essential oils of some Lamiaceae species and the antimicrobial and antioxidant activities of the entire oils. J Agric Food Chem 2006;54:1822-8.

5. Anonymous. European pharmacopoeia, 3rd ed. Strasburg, France: Council of Europe, 1996:121-122.

6. Satyal P, Murray BL, McFeeters RL, Setzer WN. Essential oil characterization of Thymus vulgaris from various geographical locations. Foods 2016;5:70.

7. Souza MA, Lemos MJ, Brito DM, Fernandes MS, Castro RN, Souza SR. Production and quality of menthol mint essential oil and antifungal. Am J Plant Sci 2014;5:3311-8.

8. Negahban M, Saeedfar S. Essential oil composition of Thymus vulgaris L. Russian J Biol Res 2015;3:35-8.

9. Adams RP. Identification of essential oil components by gas chromatography/mass spectroscopy. Carol Stream: Allured Publishing Co., 1995:18-43, 57-332.

10. Sandra PC. Capillary gas chromatography in essential oil analysis. In: Bicchi, editors. Heidelberg: Dr. A. Huethig, 1987:259-74, 287-328.

11. Singleton VL, Rossi JA. Colorimetry of total phenolics with phosphomolybdic-phosphotungstic acid reagents. Am J Enol Vitic 1965;16:144-58.

12. Gyamfi MA, Yonamine M, Aniya Y. Free-radical scavenging action of medicinal herbs from Ghana: Thonningia Sanguine on experimentally-induced liver injuries. Gen Pharmacol 1999;32:661-7.

13. Saboon, Arshad M, Ahmad MS, Mashwani ZR. Fermentation enhances redox protective activities of Gymnosporia royleana Wall. ex Lawson extracts. Iran J Sci Technol Trans Sci 2017;43:1-7.

14. Jerkovic I, Mastelic J, Milos M. The impact of both the season of collection and drying on the volatile constituents of Origanum vulgare. L. spp. hirtum grown wild in Croatia. Int J Food Sci Technol 2001;36:649-54.

15. Sadjia B, Naima S, Chahrazed B. Extraction of thyme (Thymus pallecens de Noé) essential oil by steam-distillation, steam-diffusion and hydro-distillation processes: optimization of operating conditions and antioxidant activity. J Essent Oil Bear PI 2012;15:336-47.

16. Verma RS, Rahman L, Verma RK, Chauhan A, Yadav AK, Singh A. Essential oil composition of menthol mint (Mentha arvensis) and peppermint (Mentha piperita) cultivars at different stages of plant growth from Kumaon region of Western Himalaya. J Med Aromat Plant 2010;1:13-8.

17. Rota MC, Herrera A, Martínez RM, Sotomayor JA, Jordán MJ. Antimicrobial activity and chemical composition of Thymus vulgaris, Thymus zygis and Thymus hyemalis essential oils. Food Control 2008;19:681-7.

18. Sartoratto A, Machado AL, Delarmelina C, Figueira GM, Duarte MC, Rehder VL. Composition and antimicrobial activity of essential oils from aromatic plants used in Brazil. Braz J Microbio 2004;35:275-80.

19. Mickienė R, Ragažinskienė $O$, Bakutis B. Antimicrobial activity of Mentha arvensis L. and Zingiber officinale R. essential oils. Biologija 2011;57:92-7.

20. Horváth P, Koščová J. In vitro antibacterial activity of Mentha essential oils against Staphylococcus aureus. Folia Vet 2017;61:71-7.

21. Mota LK, Oliveira PF, de Oliveira WA, Lima IO, de Oliveira LE. Antifungal activity of Thymus vulgaris L. essential oil and its constituent phytochemicals against Rhizopus oryzae: interaction with ergosterol. Molecules 2012;17:14418-33.

22. Koleva LL, Van Beek TA, Linssen JP, De Groot A, Evstatieva LN. Screening of plant extracts for antioxidant activity: a comparative study on three testing methods. Phytochem Anal 2002;13:8-17.

23. Alizadeh A, Alizadeh O, Amari G, Zare M. Essential oil composition, total phenolic content, antioxidant activity and antifungal properties of Iranian Thymus daenensis subsp. daenensis Celak. as in influenced by ontogenetical variation. J Essent Oil Bear PI 2013;16:59-70.

24. Mancini E, Senatore F, Del Monte D, De Martino L, Grulova D, Scognamiglio M, et al. Studies on chemical composition, antimicrobial and antioxidant activities of five Thymus vulgaris $\mathrm{L}$. essential oils. Molecules 2015;20:12016-28. 